EstAg 34 (1999) 31-63

\title{
Título cristológico «cordero» en Fray Luis de León
} Estudio teológico-místico *

\section{Tema:}

Tres virtudes simbolizan principalmente a Cristo como Cordero: la mansedumbre, la pureza y el sacrificio.

\section{Esquema}

INTRODUCCIÓN

$11^{\text {a }}$ PARTe: CRisto es Cordero por su Mansedumbre

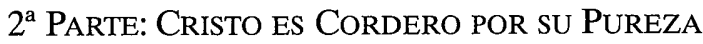

$3^{\text {a }}$ PARTE: Cristo es Cordero POR SU SACRIFICIO

\section{Introducción 1}

Los dialogantes no creen necesario probar que el nombre Cordero es nombre de Cristo, porque cada día oímos en la misa aquellas palabras que el

* Las citaciones del texto "De los nombres de Cristo" están tomadas: a) De las Obras Completas Castellanas de Fray Luis de León, $5^{\mathrm{a}}$ edición, preparada y anotada por el P. Félix García, BAC 3a y 3b. Madrid, 1991; Citaré así: BAC y la página respectiva; b) "De los nombres de Cristo", por Fray Luis de León, $4^{\mathrm{a}}$ edición, ajustada a la $3^{\mathrm{a}}$, preparada y anotada por el P. Valentín Ma. Sánchez Ruiz. "Apostolado de la Prensa". Madrid, 1946. Citaré así: AP y la página correspondiente.

1. A su muerte (1591) dejó Fray Luis totalmente redactado el nombre de Cordero, que salió a luz en la $4^{\mathrm{a}}$ edición de los Nombres. El nombre de Cordero debería ir intercalado entre el nombre de Hijo y el de Amado. Y así pensó, sin duda, hacerlo Fray Luis, de haber podido retocar la $4^{\text {a }}$ edición de 1595, teniendo para ello que reformar el comienzo del diálogo del nombre Amado. Para evitar este inconveniente, desde la $4^{\mathrm{a}}$ edición, se ha colocado este nombre al final del nombre de Jesús, que es el que en realidad cierra, con su acorde final, la maravilla de los Nombres de Cristo. Notas del P. Félix García. BAC 5ª ed. Madrid 1991 pp. 803 y 806. 
Bautista dijo a Cristo: Este es el "Cordero de Dios", que lleva sobre sí los pecados del mundo 2 .

A Jesús se le compara con un cordero ${ }^{3}$ o se le llama cordero ${ }^{4}$. De esta manera el cuarto evangelio introduce el testimonio del Bautista sobre Jesús.

El Bautista da testimonio, no sólo de la preexistencia de Jesús: "Existía antes que yo" 5 , sino también de la fuerza expiatoria de su muerte. Enuncia, a este fin, algunas imágenes y términos que sirven para describir a Jesús, muy parecidos a las palabras del mismo Jesús: "Yo soy" ${ }^{6}$, para identificarse, que hallamos también en el cuarto evangelio.

El genitivo de Dios designa a Jesús como el que cumple en sí la realidad designada por la imagen del cordero.

En otras palabras: Jesús es el verdadero Cordero ${ }^{7}$, que quita los pecados del mundo. Jesús cumple, pues, en sí la realidad designada por la imagen de los corderos destinados al sacrificio en el Antiguo Testamento ${ }^{8}$.

En la imagen del $\operatorname{Cordero~}^{9}$, la humillación e impotencia aluden a la anonadación del crucificado. La imagen simboliza, sin enbargo, al Mesías como rey, y no es signo de debilidad sino de redención.

2. Jn 1,29: Amnós, en el griego. Lo hallamos 4 veces en el N. T., en referencias cristológicas.

3. Act 8,$32 ; 1$ Pe 1,19 .

4. Jn 1, 29.36; cf. H. BAlz. G. SCHNeIDER (Eds.). Diccionario Exegético del Nuevo Testamento I. Traducido por Constantino Ruiz-Garrido. Ediciones Sígueme. Salamanca, 1996. pal. amnós v. I pp. 209-210.

5. Jn 1,30 .

6. Égw eimí. A). Efectivamente, Jesús se presenta en el Evangelio de Juan con la expresión: Yo soy sin complemento alguno: a) "Yo soy, no temáis" (Jn 6, 20), caminando sobre las aguas, como dueño de la naturaleza; b) "cuando levantéis al Hijo del hombre, entonces sabréis que Yo soy" (Jn 8,28): c) "Antes que Abrahán existiera, Yo soy, es decir, Yo existo (Jn 8, 58). La expresión Yo soy la pronuncia siempre Jesús como respuesta a una situación concreta.

B). Otras veces, la expresión Yo soy va acompañada de una denominación concreta: a) "Yo soy el Mesías y el Cristo, que hablo contigo" (Jn 4,25-26); b) "el buen Pastor" (Jn 10,11.14) y contexto de los vv. siguientes; c) "Yo soy rey". Nací para eso (Jn 15, 37); d) "Yo soy el Maestro y el Señor" (Jn 13, 3). Tanto éste "Yo soy" como el "Yo soy" sin complento alguno, son mucho más que "aquí estoy". En efecto, los guardianes enviados a prender a Jesús caen en tierra ante estas palabras (Jn 18,6).

C). Yo soy lleva otras veces especificaciones que identifican a Jesús con una misteriosa realidad: a) "El pan de la vida" (Jn 6, 48); "el pan vivo" (Jn 6, 51); b) "la luz del mundo" (Jn 8,12; 9,5; v. Jn 12, 36.46; 11, 9.10); "la puerta de las ovejas" (Jn 10, 7.9); "el camino, la verdad y la vida" (Jn $14,6)$ : "la vid verdadera" (Jn 15, 1.5); "la resurrección y la vida" (Jn 11, 25). En la mayoría de los casos, esta realidad misteriosa la sugiere una situación concreta y Jesús se identifica con esa realidad.

7. Cf. Jn 1,$9 ; 6,32 ; 15,1$.

8. Cf. 1 Pe $1,19$.

9. En el Ap: arníon, originariamente diminutivo de àrén (cordero, carnero, oveja) es la denominación más frecuente de Cristo: v. H. BALz. G. SchneIDER, Diccionario Exegético del Nuevo Testamento, v. I pp.211-212. 
En Juan 10 encontramos también la palabra cordero en plural, referida a la comunidad, en las palabras de Jesús resucitado, dirigidas a Pedro: Apacienta mis corderos, apacienta mis ovejas ${ }^{11}$. Y, en sentido figurado, leemos en Lucas: Mirad que os envío "como corderos" en medio de lobos 12.

Los discípulos de Jesús, que han de ir sin bolsa, ni alforja, ni zapatos ${ }^{13}$ en su misión, son lo mismo que corderos, expuestos a los mayores peligros, en medio de mil tribulaciones, antes de que llegue el fin de los tiempos. Jesús es, pues, en sentido propio, el Cordero sin mancha y sin techo, el Cordero inmaculado ${ }^{14}$.

\section{Contexto global del testimonio del Bautista}

Ante la pregunta de los judíos enviados desde Jerusalén: ¿Quién eres? ${ }^{15}$, el Bautista rechaza los tres títulos sugeridos por ellos. Dice no ser: el Cristo, ni Elías ${ }^{16}$, ni el Profeta ${ }^{17}$. Ellos le preguntaron: “¿Por qué, pues, bautizas?”. La pregunta era totalmente lógica. Sin estos títulos, su bautismo no era salvífico. El Bautista precisa: Yo soy la voz que clama en el desierto.

$\mathrm{Al}$ referirse a Isaías ${ }^{18}$, el Bautista se presenta como la personificación del testimonio del Antiguo Testamento. En el contexto, el Bautista parece intentar que la atención a él pase a la persona de Jesús. Por eso dice: "Yo bautizo con agua, pero en medio de vosotros está uno a quien no conocéis, que viene detrás de mí, y a quien no soy digno de desatarle la correa de su sandalia" 19 . Viene "detrás de mí", es decir, el bautismo de Juan preanuncia el bautismo del Espíritu, del que hablará luego.

No soy digno de desatar la correa de su sandalia. ¿Alude al Exodo 3, 5? Es posible. En tal hipótesis, la expresión del Bautista significaría que la santi-

10. Jn 21, 15: Tà arnía.

11. Jn $21,16.18$.

12. Lc 10, 3. Lucas emplea la palabra àrnén, àrnás, en plural, con el mismo significado que amnós $=$ cordero. .

13. Lc $10,4$.

14. a-spilos = àmnós: $1 \mathrm{Pe} 1,19$. En sentido ético, hallamos esta expresión en: $1 \mathrm{Tm} 6,14$; Sant 1, 27; 2Pe 3, 14; v. P. HeRMAS, visión 4, 3.5; símbolos: 5, 6.7; 2Clemente 8, 6.

15. Jn 1, 26-34.

16. Según la creencia judaica, Elías debía volver. En caso de ser el Bautista, habría irrumpido de nuevo en la historia judía: Ml 3, 23-24: Mt 17, 10-13.

17. El Profeta, es decir, Moisés, profeta por excelencia (v. Jn 1, 19-22). Los judíos esperaban al Mesías como el nuevo Moisés. El Mesías, en tal caso, haría mayores prodigios aún que los narrados en el Éxodo. El mismo Jesús se presenta como superior a Moisés (v. Jn 3, 13; 6, 31-33. La gente estaba también en esta creencia (v. Jn 7, 40; Hch 3, 22-23; Hbr 3, 1-11. En estos pasajes se contrapone, como superior, Cristo a Moisés.

18. Is 40,3 .

19. Jn $1,26-27$. 
dad de Jesús era tan grande como la de Javé. En efecto, Moisés, para hablar con Javé, debe descalzarse ${ }^{20}$. El Bautista se siente incluso indigno de desatar la sandalia de Jesús.

Juan intenta dar a conocer al desconocido, ya presente. Los judíos buscan a uno, que está ya presente $y_{4}$ a pesar de ello, no le conocen, porque se presenta de un modo totalmente inesperado y no aceptado por ellos.

El testimonio del Bautista es claro: Jesús es precisamente aquél que Juan ha negado ser él mismo: Jesús es el Mesías y trae la salvación. Es un testimonio bien concreto, que se inserta en la historia antigua de Israel y explica su historia actual. Es más, el testimonio de Juan parece dirigirse al mundo entero. En efecto, al día siguiente de este encuentro, Jesús llegó de nuevo al Bautista en el Jordán. Juan le descubre entre la multitud y amplía su testimonio en favor de Jesús. La embajada ya ha desaparecido de escena. El Bautista habla, pues, también a todos los presentes. Al ver a Jesús, señalándole, dice: $\mathrm{He}$ aquí el "Cordero de Dios", que quita el pecado del mundo.

Los discípulos de Juan, impresionados por estas palabras, dejaron a su maestro, siguieron a Jesús que se alejaba, le acompañaron hasta su morada y pasaron con él el resto del día. Eso intentaba Juan: desaparecer él para que apareciera Jesús.

La metáfora de Juan, que llama a Jesús cordero, recordaba a los judíos los auténticos corderos, que eran inmolados diariamente en el Templo de Jerusalén especialmente durante la Pascua.

La unión entre los dos conceptos de cordero: víctima e Hijo de Dios, debía estar muy viva en el corazón de Juan. ¿Se refiere el Bautista al cordero pascual espiatorio de la Pascua Judía? ${ }^{21}$. Esta hipótesis parece encuadrar fácilmente en el contexto del cuarto evangelio, que presenta a Jesús como el Cordero de Dios. El significado es claro: Jesús, Cordero de Dios, quita el pecado del mundo y trae la salvación, expiando el pecado con su muerte. Es éste un título existencial, que presenta a Jesús resolviendo una profunda necesidad humana.

\section{El Espíritu, el Hijo de Dios, el Cordero de Dios}

El Evangelio dice luego que el Espíritu bajaba del cielo como una paloma y se quedaba sobre Jesús ${ }^{22}$. Esta expresión define la obra esencial del

\footnotetext{
20. "Quítate las sandalias de tus pies..." $(\mathrm{Ex} 3,5)$.

21. Cf. Ex 12, 1-14.

22. Jn 1,32 .
} 
Mesías 23. Por eso, Jesús, después de ser "alzado", de volver al Padre y de ser glorificado, difundirá su Espíritu en el mundo ${ }^{24}$.

El Bautista reconoció, pues, a Jesús al ver bajar sobre Él el Espíritu 25. Como en Isaías ${ }^{26}$, el Espíritu caracteriza la misión del siervo de Dios ${ }^{27}$. Con el cambio explicativo siervo-Hijo Juan piensa, pues, en Jesús siervo de Dios al comienzo de su carrera, que inaugura con su bautismo en el Espíritu.

Que quita el pecado del mundo, indica que Cristo borra los pecados llevando a los hombres su palabra, que los hace libres del maligno.

En la unión de las imágenes de siervo y cordero se encierra, pues, toda la salvación de Jesús con su palabra y su pasión. En efecto, el Apocalipsis pinta al Cordero como sacrificado 28 y vencedor de los enemigos ${ }^{29}$. Esto expresa, por una parte, la identidad constante del Señor crucificado y glorificado, y, por otra, la seguridad de una definitiva victoria sobre los enemigos ${ }^{30}$.

Las palabras del Bautista: Yo le he visto y doy testimonio de que éste es el Hijo de Dios, aclaran, aún más, el sentido completo.

Los títulos El Cristo ${ }^{31}$, Jesús ${ }^{32}$, el Cordero de Dios, que quita el pecado del mundo ${ }^{33}$, el que bautiza en el Espíritu Santo ${ }^{34}$ y el Hijo de Dios ${ }^{35}$, se refieren, por tanto, a una misma persona ${ }^{36}$.

\section{El último testimonio del Bautista sobre Jesús}

El cuarto evangelio señala más adelante 37 el último testimonio del Bautista sobre Jesús, que complementa el testimonio anterior. En efecto, Jesús ha

23. Es decir, regenera a la humanidad en el Espíritu Santo, porque el Espíritu reposaba sobre él (v. Is 12,$2 ; 42,1 ; 61,1 ;$ Hch 1,5 .

24. El Mesías podrá dar el Espíritu a los hombres después de su resurrección. Será el Bautismo del Espíritu (v. Jn 7, 39; 14, 26s; 16, 7.8; 20, 22 y passim en otros lugares.

25. In 1,32 s.

26. Is 42,1 .

27. Cf. Mc 1,10 s.

28. Ap 5,6;13,8.

29. Ap 5,$6 ; 14,10 ; 17,14$.

30. Sobre este tema v: J. LEAL, "El sentido soteriológico del Cordero de Dios en la exégesis católica". (Jn 1, 29-36). "Estudios Eclesiásticos" 24 (1950) 147-182; idem: "Exégesis catholica de Agno Dei in ultimis viginti annis", VD 28 (1950) 98-109; P. SAMAIN, "L'Agneu de Dieu qui ôte les péchés du monde", "Revue Diocésaine de Tournai"1(1946) 165-170.

31. Jn $1,20.25$.

32. Jn 1, 29.

33. Jn 1,33 .

34. Jn 1, 34.

35. Cf. S. SABUGAL, Xristós (Investigación exegética sobre la cristología joanea). Ed. Herder, Barcelona 1972 pp. 162-183. El autor estudia con profundidad este tema y ofrece una amplia blibiografía.

36. Jn $1,35.36$

37. Jn 3,26.30; v. Commento della Bibbia Liturgica. Antico e Nuovo Testamento. Varios autores. Terza edizione. Roma 1982 pp. 39s. 
hablado a Nicodemo ${ }^{38}$ del bautismo que procede del Espíritu y que lleva consigo: una "total transformación", un "nacer de lo alto", un "nacimiento del Espíritu".

El tema ha sido preparado por el testimonio mismo del Bautista sobre Jesús ${ }^{39}$. Los discípulos de Juan creen que el éxito de Jesús se debe a tales testimonios y por eso dicen a Juan: "Rabí, el que estaba contigo al otro lado del Jordán, aquél de quien tú diste testimonio, mira, está ahora bautizando y todos se van tras él" 40 .

La escena da pie al Bautista para dar un nuevo testimonio de Jesús. La cuestión parece presentada únicamente para insertar el tema que el evangelista intenta. El Bautista reafirma nuevamente su testimonio sobre Jesús: Nadie puede recibir nada si no se le ha dado de lo alto ${ }^{41}$. El éxito de Jesús viene, pues, de lo alto. Jesús es el enviado de Dios ${ }^{42}$. Juan es el precursor, "enviado delante de él" 43. Cuando aparece el mayor, el menor debe quedar en la sombra.

La tarea del Bautista era precisamente esa: presentar a Jesús y con ello su misión quedaba cumplida. Por eso termina así su testimonio sobre Jesús: Esta es mi alegría, que ha alcanzado su plenitud. Es preciso que Él crezca y yo disminuya ${ }^{44}$.

Como testigo, Juan ha servido de pedestal, ha descubierto a Jesús, le ha preparado el camino y ha llevado a los hombres a la Luz que debía iluminar al mundo.

\section{Recordemos brevemente:}

En las palabras del Bautista: He aquí el Cordero de Dios, que quita el pecado del mundo ${ }^{45}$, recoge el cuarto evangelio uno de los simbolismos más importantes de la cristología joánica. Reúne, en una sola realidad: a) El recuerdo del cordero y la imagen del siervo de Isaías ${ }^{46}$, que carga con los pecados del hombre y se ofrece como Cordero expiatorio ${ }^{47}$; b) la memoria de la Pascua judaica y el rito del Cordero pascual ${ }^{48}$; c) el símbolo de la redención de Israel ${ }^{49}$.

38. Jn 3, 1-21.

39. Cf. Jn 1, 7-8.15.26s.32-34.

40. Jn 3, 26-27.

41. Cf. Jn 19, 11.

42. Jn 1,34 .

43. Jn $3,28$.

44. Jn 3,30 .

45. Jn 1, 29; cf. Ap 5, 6.12.

46. Is 53 .

47. $\operatorname{Lv} 14$.

48. Ex 12, todo el capítulo, pero especialmente los vv. 1-14.21-28.43-51; cf. Jn 19, 36.

49. Cf. Hch 8, 31-35; 1Cor 5, 7; 1Pe 1, 18-20. 
El cuarto evangelio presenta a Juan como un testigo cualificado de Jesús. El mismo Bautista se reconoce como testigo excepcional, cuando presenta el anuncio de Isaías: Yo soy la voz que clama en el desierto 50.

En otras palabras: El Bautista no es ni el Mesías, ni Elías, ni el profeta. Es simplemente el mensajero, y su testimonio muestra a Jesús: a) Como el Cordero de Dios, cordero pascual, o sacrificial o las dos cosas a un tiempo; b) como el verdadero poseedor del Espíritu; c) como el elegido de Dios; d) como el Mesías prometido.

Al llamar a Cristo Cordero de Dios, el Bautista anuncia, pues, la muerte expiatoria de Jesús. Dios mismo se lo ha señalado: Jesús es más que Elías y que Moisés. Juan, ha visto a Jesús y es su testigo. Jesús es el Mesías ${ }^{51}$ y el Hijo de Dios 52 .

\section{El título cristológico "Cordero de Dios", reflejado en la Patrística}

La Patrística desarrolla el simbolismo cristológico de Cordero de Dios inspirándose en los textos del Éxodo y del Nuevo Testamento, estudiados arriba.

Para la simbología cristológica del cordero pascual, los Padres se inspiran principalmente en Ex 12, 3-13 y 1Cor 5,7; para la tipología del cordero inmolado por nuestros pecados, en Isaías 53, 7; para el cordero, como figura de Cristo redentor y dueño del mundo, en el paso de Juan 1, 29 y en el Apocalipsis 5, 8. Veamos:

a) Clemente Alejandrino y Orígenes (ss. $2^{\circ}-3^{\circ}$ ).

El título cristológico "Cordero de Dios", como nombre de Cristo por antonomasia, lo vemos en Clemente Alejandrino ${ }^{53}$ y en Orígenes 54.

\section{b) San Justino (s. $2^{\circ}$ ) y Orígenes.}

La imagen del cordero pascual inmolado del Ex 12,7.8, como figura de la inmolación de Cristo ${ }^{55}$, la hallamos reflejada en la celebración del banquete eucarístico en san Justino y en Orígenes: Para san Justino, por ejemplo: “El misterio del cordero que Dios mandó sacrificar como Pascua, era figura de

50. Is 40,3 .

51. Jn 1, 20-21.

52. Jn 1,34

53. Clem. Alej., Paed. I, 5, $24,4$.

54. ORÍGENES, Comm. in Jo VI, 52.

55. Ex 5,7: La sangre, que debía untar las jambas de las puertas de las casas de los hebreos en las que se inmolaba el cordero, salvaba a los israelitas de la muerte. 
Cristo, con cuya sangre..., untan los que en Él creen sus casas, es decir, a sí mismos" 56 . Y doctrina muy parecida a ésta hallamos también en Orígenes ${ }^{57}$.

c) Melitón de Sardes (s. $2^{\circ}$ ).

El concepto de la preexistencia de Cristo domina la teología de Melitón de Sardes: "Nacido (dice) como hijo, conducido como cordero, sacrificado como una oveja, enterrado como un hombre, resucitó de entre los muertos como Dios, siendo por naturaleza Dios y hombre" 58 . Y también estas bellísimas palabras: "Éste es el cordero, que fue inmolado, éste es el cordero que permanecía mudo, éste el que nació de María, la blanca oveja" ${ }^{59}$.

d) Clemente Alejandrino, Orígenes (ss. $21-3^{\circ}$ ) y

Epifanio de Salamina (ss. $4^{\circ}-5^{\circ}$ ).

El simbolismo cristológico de cordero, referido a Cristo, sacrificado por los pecados del mundo de $1 \mathrm{Pe}, 1,19$ : "Habéis sido liberados con la sangre preciosa de Cristo, cordero sin mancha y sin tacha", lo hallamos en Clemente Alejandrino ${ }^{60}$, en Origenes ${ }^{61}$ y en Epifanio de Salamina ${ }^{62}$.

\section{e) San Agustín (ss. $4^{\circ}-5^{\circ}$ )}

San Agustín habla en numerosos sermones de Cristo como cordero:

- Refiriéndose, por ejemplo, a la mansedumbre y fortaleza de Cristo cordero, dice en el sermón 263: "A Cristo se le llama, a la vez, león y cordero: león por su fortaleza, cordero por la inocencia; león en cuanto invicto (por su resurrección), y cordero en cuanto manso" 63.

- Y en el sermón 375 A: “¿Quién es éste, cordero y león a la vez? En cuanto cordero, sufrió muerte y en cuanto león, la aniquiló..., cordero en la pasión, león en la resurrección" 64.

- Interpretando el paso de $1^{\text {a }}$ Cor 5,7: “Cristo, nuestra Pascua, ha sido inmolado", dice en el sermón 229 C: Los judíos "dan muerte cada año a un cordero, pero no conocen lo que el cordero significaba... Tienen la ley y los

56. S. Justino, Diál., 40,1; v. 13,5; 114,2, citando a Is 53,7 .

57. ORÍGEnES, Hom. 13 in Lc; cf. Passio Andreae 6.

58. Melitón de SARdes, Hom. sobre la Pasión (Pascua) 8, 10.

59. Idem 70-71; cf. Tertuliano, $A d v$. Jud. 10,18; s. CiPRIANo, Ep. 63, (un verdadero tratado); Id. Ad Demetr. 22.

60. Clemente Alej., Paed. I, 51.

61. ORIG. Comm. in Jo VI, 51,52.

62. EPIFANIO, Haer., 69.

63. Sermón 263,2.

64. S. $375 \mathrm{~A}, 1.7$. 
profetas (Lc 16,29), y no quieren reconocer lo que la ley prefiguraba mediante la Pascua. Como lo establecía la ley, el pueblo se alimentó con la muerte de un cordero; como lo predijo el profeta, Cristo fue llevado al sacrificio como cordero" 65 .

- Recuerda el paso de Isaías 53,7 cuando dice en el sermón 229 N: Para que las ovejas fuesen miembros suyos, "fue conducido al sacrificio como una oveja".

- Y el paso de san Juan 1,29 estudiado arriba: "Para que las ovejas se hiciesen miembros suyos, se dijo de él: He aquí el Cordero de Dios, que quita el pecado del mundo" 66.

- En el sermón $229 \mathrm{P}$ hace alusión a la idea, estudiada al principio, cuando dice que Cristo convierte en corderos a los bautizados. "De él se dijo: $\mathrm{He}$ aquí el Cordero de Dios" ¿Cómo los convirtió en corderos propios? He aquí el que quita los pecados del mundo. De esta manera convirtió en corderos a estos que ahora vemos vestidos de blanco" 67.

- Y en este mismo contexto llama corderos a Esteban y Pablo 68. De Esteban dice que era buena oveja y buen cordero, que "como buena oveja, siguió las huellas de su Pastor; como buen cordero, siguió al Cordero, cuya sangre quitó el pecado del mundo" 69 .

San Agustín habla de este tema en una treintena de sermones al menos, y en otros lugares de sus obras, con un significado muy afín a los arriba cita$\operatorname{dos} 70$.

\section{Parte: Cristo es Cordero por su Mansedumbre}

Fray Luis comienza diciendo que es fácil y claro afirmar que el nombre de Cordero pertenece a Cristo, pero que es escondido y misterioso lo que encierra en sí toda la razón de este nombre ${ }^{71}$. Refiriéndolo expresamente a Cristo, significa:

65. S. $229 \mathrm{C}, 1$.

66. S. $229 \mathrm{~N}, 1$.

67. S. $229 \mathrm{P}, 4$.

68. S. 316, 5 .

69. S. 319,4. En cuanto a la razón del cambio de la traducción literal de oveja por cordero, v. "Cuestiones sobre el Pentateuco", II, 41.42.

70. La alusión al tema del cordero y de la Pascua es frecuente en san Agustín de una manera directa o indirecta. En el sermón $272 \mathrm{~B}, 6$, por ejemplo, hace el Santo una ingeniosa combinación de números, para llegar a los 50 días de la celebración de la Pascua, cuando se promulgó la ley, como figura del Espíritu Santo, enviado a los 50 días después de la Resurrección de Jesús.

71. BAC 806. 
a) Mansedumbre de condición, b) y pureza e inocencia de vida, c) y satisfacción de sacrificio y ofrenda.

Aduce, a este propósito, estas palabras de san Pedro, en las que se puede apreciar el contraste continuo de la mansedumbre de Cristo con el sufrimiento que padecía, partiendo de este principio: El no hizo pecado, ni se halló engaño en su boca; que 72: a) "siendo maldecido, no maldecía; b) y padeciendo, no amenazaba; c) antes se entregaba al que le juzgaba injustamente, el que llevó a la cruz sobre sí nuestros pecados" 73 .

Cordero simboliza, en primer lugrar, mansedumbre, y conviene a Cristo por el extremo de mansedumbre que tiene "así en el trato como en el sufrimiento; así en lo que por nosotros sufrió, como en lo que cada día nos sufre".

Fray Luis apoya esta afirmación en estas palabras del primer poema del siervo del Señor en Isaías: "No será bullicioso, ni inquieto, ni causador de alboroto" 74. Y las palabras que el propio Jesús dice de sí mismo: "Aprended de mí, que soy manso y de corazón humilde" 75.

\section{Mansedumbre de Jesús en su vida mortal, en la Eucaristía, en las reprensiones}

a) En su vida mortal:

Añade Fray Luis estas palabras de hondo significado místico: El, cuando vivió nuestra vida, fue: “Con los humildes, humilde; con los más despreciados, más amoroso; con los pecadores, dulcísimo". Y continúa con el mismo sentido místico: La mansedumbre del Cordero "admitió a la mujer adúltera... y tomó ocasión para absolverla del 76 faltarle acusador, pudiendo solo El ser acusador y testigo" 77 .

72. "que" = el cual, por qué.

73. $1 \mathrm{Pe} 2,22-24$. Este paso hace continuas referencias al "siervo sufriente" de Isaías 53, que nos trae la salvación y nos enseña cómo debemos soportar el sufrimiento.

74. Is 42,4. Los dos cánticos, unidos temáticamente, (42,1-4 y 5-7). El primero se refiere probablemente a Ciro, al que se llamó "siervo del Señor", pero muy pronto se le dio un sentido mesiánico como a los demás "cantos del Siervo". De ellos se sirvieron los autores neotestamentarios para una mayor comprensión de la figura de Jesús, que "viene a abrir los ojos a los ciegos, sacar de la cárcel a los cautivos etc" (segundo cántico).

75. Mt 11,29. La "mansedumbre" y la "humildad" eran títulos clásicos de los "pobres" en el A. Testamento (v. Daniel, 3,87: "Cántico de los tres jóvenes" y Sofonías 2,3). Jesús enuncia las "Bienaventuranzas" especialmente para los "pobres y los humildes", y se considera maestro autorizado para predicar este mensaje a los pobres. Estaba previsto el rechazo de Jesús y por eso quiso revelar su mensaje especialmente a los pobres, humildes y sencillos, como estaba anunciado del "Siervo de Javé" (Is 61,1-2), paso que cita Lucas 4,18; v. también Mt 12,18-21; 21,5).

76. "del" faltarle acusador = porque faltó acusador.

77. En la Samaritana Jesús condena la culpa, pero salva a la persona y muestra que nosotros, que somos pecadores, debemos tener indulgencia con el prójimo. La enseñanza de este pasaje es clara: Jesús prohibe emitir juicios duros sobre los demás en relación con su culpabilidad (v. 
Esta misma mansedumbre "admitió a la mujer pecadora", escena que subraya la misericordia de Jesús con los pecadores, y llamó "a su presencia a los niños que sus discípulos apartaban de ella" 78 .

Este paso, aducido aquí por Fray, acerca de la mansedumbre de Jesús con los niños, indica la actitud que han de tener sus discípulos ante Dios y con los hermanos. Por lo demás, esta actitud de Jesús es uno de los signos fundamentales de la llegada del Reino.

El mismo significado tiene la acogida de Jesús a las "largas razones de la Samaritana" 79 , aducido también por fray Luis. Las palabras de Jesús: "Si conocieras el don de Dios" etc., ${ }^{80}$ aclaran el sentido profundo de este paso. El don de Dios es "el agua viva", "la salvación", "la vida eterna" 81.

\section{b) En la Eucaristía:}

Ahora, en la Eucaristía, "lleva con mansedumbre verse rodeado de mil impertinencias y vilezas de hombres, y no hay aldea de tan pocos vecinos adonde no sea casi como uno de ellos en su iglesia nuestro Cordero blando, manso, sufrido a todos los estados" 82 .

\section{c) En las reprensiones:}

Ni siquiera la actitud de Jesús con san Pedro cuando pretendió apartarle de su pasión ${ }^{83}$, con los fariseos ${ }^{84}$ y con los mercaderes del templo ${ }^{85}$, "encendió su corazón con fiereza", sino en todos "conservó el sosiego de mansedumbre, desechando la culpa y no desdiciendo de su gravedad afable y dulce".

Lc 9, 54-55) porque Jesús vino a salvar a los pecadores, no a hacerlos perecer (Lc 19,10). Ver el precioso "comentario teológico-místico" que hace de este paso san Agustín: EvJnTr 15, 10-33 ss.

78. Lc 7,37. La unción tiene aquí un significado de conversión y de perdón.

79. Mt 18,2 .

80. Jn 4,7 .

81. "el agua viva": Recuérdese lo explicado en la Introducción sobre el "Yo soy", en que Jesús se identifica con una denominación concreta y misteriosa realidad (v. Introducción, nota 66).

82. BAC 807; AP 587.

83. Mc 8,33. El primer anuncio de la pasión y persecuciones es una enseñanza nueva y desconcertante. Jesús comienza a descubrir la verdadera naturaleza de su mesianismo. Sustituye, a este fin, el título de "Mesías", más expuesto a interpretaciones triunfalistas, por el de "Hijo del hombre", que significaba exaltación pasando por la humillación, y resurrección pasando por la muerte. Esta es la panorámica nueva que Jesús revela y que Pedro no quiere aceptar. Jesús le invita a ir detrás de él, porque el discípulo debe seguir a su maestro.

84. Mt. 23 (contexto de todo el capítulo). La duplicidad de vida y la hipocresía son el denominador común de la acusación de Jesús contra los fariseos. Jesús insiste en el desprecio y la muerte, que han hecho de los que han sido enviados, y alude probablemente también al rechazo de él mismo, enviado único de Dios.

85. Jn 2, 15. Juan quiere mostrar que Jesús inaugura unas relaciones nuevas con Dios. Jesús sustituye el templo antiguo y se presenta como el verdadero templo, lugar del encuentro de Dios con los hombres. 


\section{Reflexión teológico-mística}

Fray Luis anota luego una reflexión teológico-mística, que indica la profundidad inefable de la Providencia de Dios en sus amorosos designios, cuando dice:

"En la divinidad, sin moverse, lo mueve todo, y sin recibir alteración, riñe y corrige; y durando en quietud y sosiego, lo castiga y altera... Nunca turbó la dulzura de su ánimo manso el hacer en los otros lo que el desconcierto de sus razones o de sus obras pedía; y reprendió sin pasión, y castigó sin enojo, y fue aun en el reñir un ejemplo de amor" 86 .

Estas palabras parecen inspiradas en este paso, también de carácter teológico-místico, de las Confesiones de san Agustín:

"Amas y no sientes pasión; tienes celos y estás seguro; te arrepientes y no sientes dolor; te aíras y estás tranquilo; mudas de obra, pero no de consejo; recibes lo que encuentras y nunca has perdido nada; nunca estás pobre y te gozas con los lucros" 87 .

\section{Mansedumbre y fortaleza de Cristo}

Fray Luis insiste en que la mansedumbre de Jesús no significa debilidad. En primer lugar, dice, Cristo se llama y es León por lo que a nuestro bien y defensa toca "con los demonios enemigos nuestros, y por la manera como defiende a los suyos. Para librarlos de sus manos les quitó el mando, $y$ derrocólos de su tiranía usurpada; $y$ asolóles los templos... $y$ bajó a sus reinos oscuros $y^{88}$ sacóles mil prisioneros".

$Y$ continúa con mayor énfasis todavía: " $Y$ entonces $y$ ahora $y$ siempre se les muestra fiero, $y$ los vence, $y$ les quita de las uñas la presa". A esto se refiere la Escritura para llamarle León, cuando dice: Venció el León de Judá ${ }^{89}$.

Cristo, "León de Judá", venció siempre a satanás y al mundo. La escena del capítulo quinto e incluso del capítulo sexto del Apocalipsis, está dominada por el tema del libro, escrito por dentro y por fuera ${ }^{90}$ y sellado, que contiene los secretos misteriosos de Dios sobre la historia, que nadie puede cambiar ${ }^{91}$.

86. Estas palabras de Fray Luis coinciden, en su sentido global, con la definición de la Providencia de Dios, que da el Vaticano I, Ses. III c. 1: Denz "Ed. Herder" Barcelona, 1963 n. 1784.

87. Conf $1,4,4$.

88. Obsérvese la multiplicación de conjunciones: $y+y+y$ (polisíndeton), para dar mayor viveza a la expresión de las palabras y conceptos con los que Fray Luis expresa la fuerza de Cristo: Cordero-León = León-Cordero, mansedumbre llena de fortaleza para defender a los suyos.

89. Ap 5,5, es decir: Venció a satanás y al mundo (v. Jn I,35s; 1Jn 2,14.

90. "escrito por dentro y por fuera", es decir, todo el libro es palabra persuasiva y convincente. 91. Cf. Apoc 22, 18-19. 
Fray Luis cita, con acierto, este paso del Apocalipsis para explicar la fortaleza del Cordero. En efecto, el Mesías, León para vencer, se hizo Cordero para morir. El Cordero lleva huellas del suplicio, pero está en pie ${ }^{92}$, triunfante, vencedor de la muerte ${ }^{93}$. La sangre del Cordero, anota S. Sabugal, es considerada aquí como instrumento de la victoria sobre satanás y, por tanto, del establecimiento de "la potestad del Ungido de Dios". Uno y otro título, el Cristo y el Cordero, están estrechamente relacionados 94 .

En segundo lugar, así como nadie se atreve a quitarle

“de las uñas al león lo que prende, así nadie puede quitarle a Cristo de su mano sus ovejas" 95 .

A la pregunta de los judíos: "Si eres el Cristo, dínoslo claramente de una vez" 96 , Jesús aduce el testimonio de sus obras. La identidad de Jesús sólo puede ser conocida por aquellos que creen en él y le pertenecen. Jesús realiza las obras de su Padre, conocidas sólo por aquellos que están abiertos a la fe en él y al mensaje que anuncia.

Fray Luis cita también este paso de Isaías:

"Así como cuando brama el león y el cachorro del león sobre su presa, no teme para dejarla; si le sobreviene multitud de pastores, a sus voces no teme, ni a su muchedumbre se espanta; así el Señor descenderá y peleará sobre el monte Sión" 97.

Únicamente Dios puede salvar. El texto completo de Isaías, citado por fray Luis, emplea dos imágenes distintas, aunque complementarias: Dios será como un león con sus enemigos y con su pueblo como un pájaro, que protege a su nidada. Él es el único que libra y sus enemigos serán aniquilados.

Y concluye fray Luis: "Así que ser Cristo León le viene de ser para nosotros amoroso y manso Cordero, y porque nos ama y sufre con amor y mansedumbre infinita, por eso se muestra fiero con los que nos dañan; y cuando es con ellos fiero, con nosotros es manso".

Tenemos, pues un contraste completo en la actitud de Jesus con nosotros y con nuestros enemigos: a) A nosotros nos ama, b) a ellos los desama; a) a nosotros nos sufre, b) a ellos los maltrata; a) con nosotros es manso, b) con ellos es fiero.

92. Cf. Act 7, 55 .

93. La imagen del Cordero y León compendia la obra entera del "Siervo de Dios": a) condenado a la muerte (Is 53, 6-7; Jer 11,19; Act 8, 26s); b) la obra del "cordero pascual", que trae la liberación (Ex 12, 12-13; Jn 1,29; 1Pe 1, 18-19); c) el "Cordero vencedor" (León) y guía de su rebaño.

94. SANTOS SABUGAL, "Xristós". Investigación exegética sobre la cristología joanea. Apéndice I: "El título Xristós en el Apocalipsis. "Herder". Barcelona 1972 p. 456 y notas 35.36 y 37.

95. Jn $10,28$.

96. Id. 10,24 .

97. Is 31,4 . 
Cristo es, pues, perfecto Cordero y procede como Cordero "delante del que lo trasquila" 98. Porque "¿qué no sufrió de los hombres por amor a los hombres? ¿De qué injuria no hicieron experiencia en Él los que vivián con Él? Con palabras... con testimonios falsísimos; pusieron sus manos sacrílegas en su divina persona... Mas ni la injuria mudó la voluntad, ni en la paciencia y mansedumbre hizo mella el dolor".

Y recuerda este paso sobre Sermón del monte, de san Agustín ${ }^{99}$ :

"Hombres mansos son aquellos que ceden ante los atropellos de que son víctimas y no hacen resistencia a la ofensa, sino que "vencen el mal con el bien" 100.

El Apóstol subraya este paso de la carta a los Romanos, que no es bueno ceder a la dinámica de la violencia, dispuesta siempre a poner en práctica la ética del "ojo por ojo y diente por diente" 101 de la Ley antigua.

Al citar este paso de san Agustín, el cual hace, a su vez, referencia al Evangelio, fray Luis quiere subrayar la enseñanza de Jesús. En efecto, Jesús quiere llevar la ley a sus exigencias más perfectas. Para ello propone una vivencia interior de la ley, una vivencia en plenitud. Por eso, al explicar esta interpretación, enumera Jesús cinco ejemplos con el mismo esquema fundamental: "Habéis oído que se dijo" + la citación del Antiguo Testamento + la interpretación propia de Jesús: "pero yo os digo" etc.

El esquema incluye lógicamente mil y mil casos más, que pueden presentarse en la vida del hombre. Jesús termina así esta enseñanza: "Sed perfectos como vuestro Padre celestial es perfecto" ${ }^{102}$, que es la clave para comprender la novedad que El nos propone. Es decir: vivir con la mirada fija en el Padre celestial, que no pone barreras al amor ${ }^{103}$.

Fray Luis, siguiendo este mismo contexto, dice luego que Cristo es el extremo de mansedumbre. $\mathrm{Y}$ presenta para explicarlo algunos contrastes extremos, tan de su agrado.

Cristo, dice:

a) A los que le huyen, busca; b) a los que le aborrecen, abraza;c) a los que le afrentan y dan dolorosa muerte, con esa misma muerte los santifica; d) y con esa misma sangre, que enigmáticamente le sacan, los lava ${ }^{104}$.

98. Is 53,7. Tal vez el Bautista, al citar el paso de san Juan 1,29: "He aquí el Cordero de Dios, que quita el pecado del mundo", quiso reunir el versillo 4: "Él llevó muestras dolencias... nosotros le vimos herido de Dios y humillado", y el versillo 7: “... no abrió la boca... era llevado como un cordero al degüello y como una oveja ante los que la trasquilan".

99. Fray Luis cita aquí un tanto libremente a san Agustín, aunque, como siempre, lo hace de una manera elegante. v. Sermo Domini in monte, I, $2,4$.

100. Rom 12,21.

101. Mt 5,38; cf. Ex 21,24; Lev 24,20; Deut 19,21.

102. Mt 5,48 .

103. Cf. Mt 5,45.

104. "y los lava con su misma sangre": Invierto los términos de la frase para mayor homogeneidad con las frases anteriores. 
En otras palabras: La actitud de los hombres es: huir de Jesús, aborrecerlo, afrentarle y darle muerte, derramar la sangre de Jesús.

La actitud de Jesús, en cambio, es: buscar al hombre, abrazar a los enemigos, santificarlos con su muerte, lavarlos con su sangre.

¡Maraviloso este elenco de contrastes, señalado por fray Luis, entre la actitud de los hombres y el amor de Jesús!.

Fray Luis recuerda que no es de extrañar esta actitud de Jesús, porque "es 105 puntualmente en este nuestro Cordero lo que en el cordero antiguo, que de él tuvo figura: que todos lo comían y despedazaban, y con todo él se mantenían: la carne y las entrañas y la cabeza y los pies" 106.

El autor del Éxodo cambia este paso sobre el cordero pascual 107 en un acontecimiento salvador del pueblo de Israel. Todo en él tenía un significado salvador: a) El ritual mismo de la fiesta 108 ; b) la celebración ${ }^{109}$; c) la enumeración de los participantes en la fiesta 110 .

\subsection{Mansedumbre en su pasión. Reflexión mística}

Fray Luis concluye este paso con una reflexión mística: La relación entre los sentidos exteriores e interiores. No hubo, dice, "cosa en nuestro Bien adonde no llegase el cuchillo y el diente".

a) Sentidos externos: al costado, a los pies, a las manos, a la sagrada cabeza, a los oídos, a los ojos y a la boca con gusto amarguísimo".

b) Sentidos internos: Y pasó a las entrañas el mal, y afligió por mil maneras su alma santa".

$Y$ añade al final estas palabras, a manera de conclusión, de carácter místico todavía más hondo: Cristo obró así precisamente porque era Cordero y no Cordero solamente "sino provechoso Cordero, no solamente sufrido y manso, sino... bienhechor utilísimo. Siempre lo espinamos nosotros, y siempre Él trabaja por traernos fruto".

\subsection{Mansedumbre en sufrirnos desde el cielo}

La mansedumbre de Jesús para con nosotros continúa también en el cielo. El, dice fray Luis, "nos sufre con paciencia, y nos aguanta con sufrimiento, y nos llama y despierta y solicita con mansedumbre y amor entrañable" 111.

105. «es»= acontece, sucede.

106. BAC 810; AP 591.

107. Ex 12,1-14.

108. Id. $12,1$.

109. Id. 12, 21-28.

110. Id. 11,12 .

111. Rom 2,4 . 
Jesús no se ha desprendido de nosotros, por lo tanto, ahora en el cielo, y también ahora nos invita a imitarle en la mansedumbre y en el amor.

\subsection{La mansedumbre de Cristo nace del amor}

"Porque es tan amoroso (dice) por eso es tan manso; y porque es excesivo el amor, por eso es la mansedumbre en exceso".

Fray Luis cita de nuevo el conocido paso del Apóstol, el Himno al amor ${ }^{112}$. Porque "la caridad, de su natural ${ }^{113}$, es sufrida etc".

La actitud de Jesús es, por lo tanto, actitud de amor para con el hombre. $\mathrm{Y}$ los condicionamientos del amor verdadero son siempre de benevolencia y deseo del bien. La fuente del amor está en Dios mismo, que es el primero en amar, porque Él mismo es amor ${ }^{114}$.

Fray Luis centra todo el razonamiento de la mansedumbre de Cristo, como lo hace el Apóstol, en el amor. Sigue, en efecto, el pensamiento de san Pablo: a) $\mathrm{El}$ amor es lo principal y ante él todas las cosas desaparecen $115 ; \mathrm{b}$ ) el amor es fuente de todos los bienes $116 ;$ c) el amor permanecerá para siempre 117.

A diferencia del amor pagano, pasional y egoísta, el amor de que habla aquí el Apóstol es amor de benevolencia y se orienta hacia Dios y al prójimo. Se atribuye primero al Padre, que nos amó primero y entregó a su Hijo por amor a los hombres ${ }^{118}$. Está también en el Hijo ${ }^{119}$, porque Él ama al Padre como es amado por Él ${ }^{120}$ y como Él ama a los hombres ${ }^{121}$ por los cuales se ha entregado a la muerte ${ }^{122}$. Se halla también en el Espíritu Santo ${ }^{123}$, quien lo difunde en el corazón de los hombres ${ }^{124}$. Este amor se actualiza en la verdad 125.

Aunque aparentemente de un modo fugaz, advertidamente ha citado fray Luis estas palabras en el paso clásico del himno al amor del Apóstol a los fieles de Corinto. Por eso concluye así este apartado:

112. 1 Cor $13,1-13$.

113. "de su natural" = de suyo, por su propia condición natural.

114. 1 Jn 4, 7.8.16.19.

115. 1 Cor $13,1-3$.

116. Id. 4-7.

117. Id. $8-13$.

118. Rom 5,8; 8,32-39; 2 Cor 5, 18.21; Ef 2, 4-7.

119. Rom 8, 35.37.39; 2 Cor 5,14; Ef 3,19; 2 Tim 1,13.

120. Ef 1,6; Col 1,13; v. Jn 3,35; 14,31.

121. Jn $13,1-34 ; 14,21 ; 15,9$.

122. 2 Cor 5, 14s; Gal 2,20; Ef 5, 2-25.

123. Rom 15,30; Col 1,8.

124. Rom 5,5.

125. Ef 4,15 . 
"De manera que, cuando no hubiera 126 otro camino, por este solo del amor entendiéramos la grandeza de la mansedumbre de Cristo; porque cuanto nos quiere bien, tanto se ha con nosotros, con el mismo amor del Padre. Por eso, continúa fray Luis: "Quiérenos cuanto ve que su Padre nos quiere; el cual nos ama por tan rara y maravillosa manera, que dio por nuestra salud la vida de su unigénito Hijo" 127, como Él mismo dice: "Así amó al mundo Dios, que dio a su Hijo unigénito etc" 128.

\section{En breves palabras:}

La inciativa del amor procede siempre de Dios, se realiza por medio del Hijo, que es enviado por el Padre y que vuelve a Él por la exaltación de la cruz.

Fray Luis concluye el razonamiento de todo este punto, con estas palabras del Apóstol, a manera de colofón místico:

"Quien no perdonó a su propio Hijo, antes lo entregó por nosotros..., ¿cómo no nos dará con él graciosamente todas las cosas?" 129.

Fray Luis ha intentado, pues, con todo este discurso, invitar a los hombres a dar una respuesta de amor parecida a la de Cristo. La actitud de amor en Cristo explica su mansedumbre. Si Dios nos ama, si está con nosotros, lo demás, todo lo demás, es una mera consecuencia de este amor.

\subsection{La mansedumbre de Jesús mitiga su poder, semejante al poder de Dios}

Fray Luis continúa ponderando el amor y la mansedumbre, lo amoroso y lo manso, la grandeza y la humildad de Jesús. Por eso dice: "Cuanto uno es mayor señor y gobierna a más gentes..., tanto es ${ }^{130}$ más sufrido y más manso. Por donde 131 la Divinidad, universal emperatriz de las cosas, sufre y espera, y es mansa, lo que no se puede encarecer con palabras".

De este modo se presentó a Moisés: "Soy piadoso, misericordioso, sufrido, de larguísima esperanza..., que extiendo por mil generaciones mi bien" 132 .

Dios se revela a Moisés y proclama su ser, su vida y su actividad: Es justo y paciente; su castigo es pequeño y su misericordia, infinita ${ }^{133}$; fiel y cercano

126. «cuando no hubiera»= «aunque no hubiera».

127. BAC 811; AP 592-593.

128. Jn 3, 14-16.

129. Rom 8,32 .

130. "es" = "sea", en el texto.

131. "por donde" = por lo cual, por esto.

132. Ex 34, 6-7.

133. $\operatorname{Ex} 34,6-7$. 
a cuantos lo necesitan; ama a sus crituras y les hace sentir su cercanía. El mismo Moisés aprende la mansedumbre en su trato con el Señor, pues de él se dice que "era mansísimo sobre todos los de su tiempo" 134.

Fray Luis resume en estas breves palabras todo esta primera parte, recordando la idea de Cristo, Cordero y León, manso y poderoso, expresada arriba: "Por manera que 135 la razón convence que Cristo tiene mansedumbre de Cordero infinita: lo uno, porque es su poderío infinito; y lo otro porque se parece a Dios más que otra criatura ninguna".

Poderío y mansedumbre; fortaleza y dulzura, grandeza y humildad, divinidad y humildad.

\section{En síntesis:}

En diversos libros del N. T. (Juan, Actos, 1Pedro y especialmente en el Apocalipsis) se compara a Jesús con un cordero. El tema aparece ya en el A.T.

El profeta Jeremías, acosado por sus enemigos, se comparaba con un cordero manso, al que llevan al matadero ${ }^{136}$. La imagen se aplica a Jesús, el Siervo del Señor, que se entrega por los pecados de los hombres y es llevado a la muerte como un cordero ${ }^{137}$. Este texto, lo hemos visto arriba, es comentado por fray Luis, que subraya la humildad y mansedumbre del siervo de Javé, anunciaba el destino de Cristo ${ }^{138}$. Al mismo texto de Isaías se refieren los Evangelistas cuando subrayan que Jesús callaba ante el Sanedrín ${ }^{139}$ y ante Pilato ${ }^{140}$.

La tradición judía dio un valor redentor a la sangre del cordero pascual. Los israelitas fueron liberados de la esclavitud de Egipto y llegaron a ser un "reino de sacerdotes" y "una nación santa" 141.

La tradición cristiana, a su vez, lo hemos visto arriba, ha visto en Cristo al verdadero Cordero pascual.

Jesús es el Cordero sin mancha y sin tacha ${ }^{142}$, es decir, "sin pecado" 143 , que viene a redimir a los hombres.

El Apocalipsis conserva la imagen de Cristo, Cordero pascual, pero subraya un gran contraste entre la debilidad del cordero sacrificado y su poder actual en el cielo. Cristo comparte ahora el trono de Dios ${ }^{144}$, adornado de poder divi-

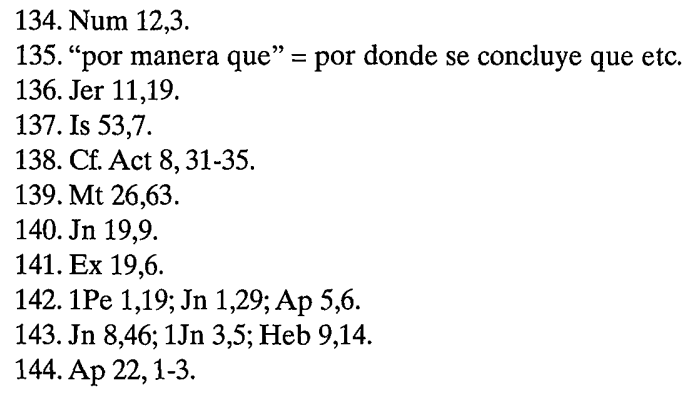


no, que recibe con Dios la adoración de los bienaventurados ${ }^{145}$. La victoria final lo consagrará "Rey de reyes" y "Señor de señores" 146. Finalmente, recobrará la primera mansedumbre, cuando celebre sus bodas con la Jerusalén celestial, simbolizada por la Iglesia ${ }^{147}$.

En este contexto escriturístico y de la tradición, Fray Luis, lo hemos visto ampliamente en esta primera parte ${ }^{148}$, subraya estos dos extremos: la mansedumbre y el poderío, la humildad y la fortaleza del Cordero, representados, respectivamente, por los simbolismos del cordero y del león.

\section{$2^{a}$ Parte: Cristo es Cordero por su Pureza}

Fray Luis da como suficientemente probada la primera parte y por eso comienza la segunda con estas palabras:

"Si es Cordero por la mansedumbre, ¿cuán justamente lo será por la inocencia y pureza?"

Y recuerda un paso de la primera carta de san Pedro, para iniciar su argumentación: Sabed que habéis sido "redimidos, no con oro y plata que se corrompe, sino con la sangre sin mancilla del Cordero inocente" 149 . Con estas palabras, comenta fray Luis, "declara y engrandece la suma inocencia de aqueste Cordero nuestro".

En la mente de fray Luis, san Pedro quiere persuadirnos de la inocencia del Cordero, que nos ha comprado con una vida tan justa y lavado del pecado con una sangre tan pura, "para que tal inocencia y pureza, ofrecida por nosotros a Dios, no carezca de efecto".

Aduce también el texto clásico de Santiago, cuando dice que "es perfecto el que no tropieza en las palabras y lengua" 150 . Y de Cristo Cordero, sin embargo, afirma que "ni hizo pecado, ni en su boca fue hallado engaño".

\section{Dios ama a Cristo más que a todas las cosas}

Fray Luis presenta un sencillo silogismo para inciar la argumentación. Helo aquí: a) Dios ama más que todo la pureza; b) Cristo es amado sobre todas las criaturas; c) luego es más puro que todas ellas.

145. Id. 5,$13 ; 7,10$.

146. Id. 17,$14 ; 19,16$.

147. Id. 19, 7-9.

148. Cf. especiamente los apartados 3 y 5 de esta primera parte.

149. 1 Pe $1,18-19$.

150. Sant 3,2 . 
Explica luego el concepto filosófico de la palabra pureza en sentido amplio, y comienza su argumentación con esta premisa de carácter general: "Lo que Dios en sus criaturas ama y aprecia más, es santidad y pureza". Y desgrana después este concepto general de pureza en varias definiciones, que podrían resumirse así:

a) Ser puro "es andar ajustado a la ley que pone Dios y con aquello que su naturaleza le pide" 151. Y continúa: "Eso mismo es la verdad de las cosas".

b) Ser puro, es "decir y responder con las obras" 152.

c) Lo verdadero responde a la realidad de las cosas. Por el contrario, "lo falso y engañoso no es" 153 .

d) "Lo que Dios manda, eso ama". En efecto, a Dios, que es el ser mismo, nada puede agradarle tanto como la pureza y la verdad.

Pureza y verdad, verdad y pureza, son tomados aquí como sinónimos, tienen un mismo significado. A Dios, suma Verdad y Santidad, nada puede agradarle tanto como la pureza, como la verdad. Por eso, fray Luis termina su razonamiento con estas palabras: "La pureza es verdad..., y la verdad es lo que más agrada al que es puro ser". Y redondea todavía más su argumentación de esta manera: "Si Dios se agrada 154 más de la humanidad santa de Cristo, concluido queda que es más santa y pura que todas las criaturas, y que aventaja en esto a todas".

Cristo es "el Hijo de su amor y de quien únicamente se complace" 155. Él es el Amado, "por cuyo amor y para cuyo servicio hizo lo visible y lo invisible que crió" 156.

La creación entera manifiesta el amor y la grandeza del Creador. En todas las cosas brilla la luz de Dios, con mayor o menor resplandor, en conformidad con la perfección específica de su naturaleza: las menos perfectas menos perfectamente, las más perfectas con mayor perfección. Esta luz brilla especialmente en el hombre, imagen viva del Creador, con mayor esplendor que en las demás criaturas.

\section{Pureza de Cristo por su cercanía a la Divinidad}

Fray Luis parte de este principio: que la cercanía de la luz proyecta luz, y la mayor cercanía del sol produce mayor resplandor. Por eso dice: "Si es más claro ${ }^{157}$ lo que al sol se avecina más, ¿qué resplandor no tendrá de santidad

151. «lo que su naturaleza le pide»= entiende aquí la naturaleza pura.

152. "responder con las obras" = es decir, "decir y hacer".

153. "lo falso no es" = es decir, lo falso es negación, carencia de realidad y, por tanto, carancia de ser.

154. "si Dios se agrada" = Dios efectivamente se agrada.

155. Cf. Mt 3,17; Mc 1,11; Lc 3,22; 2 Pe 1,17.

156. Col 1,15s.

157. "Si es más claro" = En realidad es proposición afirmativa: es más claro, aunque parece condicional. 
y virtud el que está, y estuvo desde el principio, y estará para siempre... sumido en el abismo de esa misma luz y pureza? En las otras cosas resplandece Dios; mas en la humanidad (de Cristo)... está unido personalmente...; en las otras reverbera este sol, mas en ésta hace un sol de su luz" 158.

Señala luego algunos contrastes, tan de su agrado, para resaltar el resplandor y la pureza de Cristo. Cita, al efecto, las palabras del salmo: "En el sol puso su morada" ${ }^{159}$; porque la luz de Dios puso en la humanidad de Cristo su asiento, con que quedó en puro sol transformada" 160 .

Y señala algunas antítesis específicas entre las cosas creadas y la Humanidad de Cristo. He aquí algunas:

a) "Las otras cosas centellean hermosas,- ésta 161 es de resplandor su tesoro 162 .

b) "A las otras les adviene la pureza y la inocencia de fuera,- ésta tiene la fuente y el abismo de ella en sí misma.

c) "Las otras reciben y mendigan virtud,- ésta, riquísima de santidad en sí, la derrama en las otras".

Y concluye con estas palabras de acentuado signo místico:

"Pues todo lo santo y lo inocente y lo puro nace de la santidad y pureza de Cristo y..., es partecilla que Cristo les comunica, claro es, no solamente ser más santo, más inocente, más puro que todas juntas, sino también ser la santidad y la pureza y la inocencia de todas y..., la fuente y el abismo de toda pureza e inocencia" 163 .

Trataré más extensamente este tema al hablar de la unión de la Humanidad de Cristo con la persona del Verbo.

\section{Brevemente:}

Fray Luis recuerda que la creación entera, figurada por la tierra, el cielo y el firmamento, por el ritmo de los días y las noches, entona un hermoso canto a su Creador. Todas las criaturas, con mayor o menor perfección, en conformidad con sus naturalezas, cantan un himno de alabanza a su Señor. El hombre, corona de la creación y la más excelente participación del Creador,

158. "hace un sol de su luz" = obsérvese la afinidad de estas palabras con el principio: "Luz de Luz", "Dios de Dios" etc., del símbolo Niceno-Constantinopolitano (a. 381) (Denz 85).

159. Sal 18,6.El salmo entero es un himno de alabanza a Dios por la belleza de la creación.

160. "en puro sol transformada". Recuérdese la imagen del "fuego" cambiando en fuego al "madero" y al hierro", en mi estudio "Títulos Cristologicos", "Estudio Agustiniano", Valladolid 1995 pp. 195 s. y 201 s.

161. "ésta" e. d. la Humanidad de Cristo.

162. "es de resplandor su tesoro" = es toda resplandor.

163. BAC 813-814; AP 595-596. 
debe unir también su alabanza al gran concierto de la creación, mediante la pureza de su vida.

\section{Cristo es el origen de toda pureza y santidad}

Fray Luis parte de este principio general: "Cristo es universal principio de santidad y virtud, de donde nace toda la que hay en las criaturas, y bastante 164 para santificar todas las criadas, y otras infinitas que fuese Dios continuamente creando" 165 .

Y recuerda de nuevo el testimonio del Bautista, cuando dice que Cristo "es la víctima y sacrificio aceptable y suficiente a satisfacer todos los pecados del mundo y de otros mundos sin número" 166.

Enuncia luego dos principios. El primero de aspecto aparentemente negativo, pero con fuerza positiva, cuando dice: "Ni hay grado de santidad ni manera de ella ${ }^{167}$, que no le haya en el alma de Cristo".

$\mathrm{Y}$ el segundo propiamente positivo: "Todas las bondades, todas las perfecciones, todas las... gracias, que se esparcen y hubiesen ${ }^{168}$, están... unidas, sin medida ni cuenta, en el manantial de ella, que es Cristo".

Fray Luis presenta, pues, a Cristo como la fuente de mansedumbre, de santidad y pureza. Y expone de nuevo otros dos principios para afianzar más y más la argumentación pormenorizada que va a presentar.

Primero: Únicamente el limpio puede quitar los pecados y dar la santidad. Porque es necesario, dice, que "quien cría santidad la tenga, y quien quita los pecados, ni los tenga ni pueda tenerlos".

Segundo: "No pudiera ser Cristo universal principio de limpieza y justicia, si no alejara de Él todo asomo de culpa, y si no atesorara en sí toda la razón de justicia y limpieza".

Enumera luego numerosos casos concretos, en los que resume, magistralmente, la pobreza y necesidad angustiosa del hombre y la riqueza infinita de Cristo, y su influjo en la vida y la actividad entera del hombre.

Presenta a Cristo ordenado en sus deseos, imaginación y entendimiento; perfecto en su voluntad; moderado y dueño de todos sus sentidos; exento de todo mal y pecado original y personal; adornado de todas las gracias y virtudes, para poder enriquecer al hombre con sus dones.

164. "bastante" = suficiente.

165. Cf. Jn 1, 14.16.17; 1Jn 1,2: Col 2, 9-10.

166. Jn 1,29 .

167. "ni manera de ella" = ni apecto o matiz de santidad.

168. "hubiesen" = existieran, viviesen. 


\section{Brevisimamente:}

Los dos extremos presentados ampliamente por fray Luis sobre la pobre$z a$ del hombre y la riqueza de Cristo, para poder enriquecer al hombre, podrían compendiarse de esta manera en síntesis esquemática:

a) Había hechos malos, en nosotros,- ningún hecho desconcertado y oscuro, en Cristo. Cristo.

b) Malos deseos, en nosotros,- ningún deseo que no fuese del cielo, en

c) Imaginación y entendimiento turbado, en nosotros,- un cielo sereno, en Cristo.

d) Voluntad malsana y enferma, la nuestra,- ley de justicia y salud, la voluntad de Cristo.

e) Encendidos y furiosos sentidos, los nuestros,- la misma moderación y templanza, los de Cristo.

g) Pecado primero y personales despúes, en nosotros,- no hubo ni pudo haber culpa alguna, en Cristo.

h) Fue remedio de todos nuestros pecados,- toda sombra de maldad y malicia estuvo lejos de Cristo.

i) Hará en el cielo impecables, a los hombres,- Cristo fue siempre impecable.

Una obra maravillosa la que hace Cristo en el hombre, que abarca: nuestros actos y nuestros deseos; nuestra imaginación, entendimiento y voluntad; nuestros sentidos internos y externos; nuestra culpa original y personal; nuestra impecabilidad definitiva en el cielo. Es decir, todo el ser y la actividad humana quedan sanados por la santidad y la fuerza de Cristo.

Y redondea todo este número, a manera de reflexión mística, cuando dice al final: Convino que Cristo "fuese un tesoro de inocencia y limpieza, porque era y había de ser el único manantial de ella, riquísimo. Y, como en el sol..., no veréis sino una apurada pureza de resplandor y de lumbre ${ }^{169}$, porque es de las luces y resplandores la fuente, así en este Sol de justicia, de donde manó todo lo que es rectitud y verdad, no hallaréis..., sino una sencillez pura y una rectitud sencilla, una pureza limpia, que siempre está bullendo en pureza, una bondad perfecta entrañada en cuerpo y en alma y en todas las potencias de ambos".

\section{Pureza del cuerpo de Cristo}

Fray Luis continúa en este mismo contexto, precisando más y más, al referirse concretamente a los dones del cuerpo y del alma de Cristo.

169. "Apurada pureza" de resplandor y de lumbre" = es decir, la esencia misma de resplandor y de luz. 
Introduce el tema hablando de las diversidad de cuerpos según sus estructuras y formas diferentes: Bien o mal inclinados; unos coléricos, otros mansos; unos honestos y otros poco honestos; modestos unos y humildes, otros soberbios y altivos 170 .

$\mathrm{Al}$ referirse a la pureza del cuerpo de Cristo dice: Es cosa fuera de toda duda que "el cuerpo de Cristo... era de inclinaciones excelentes, y en todas ellas fue loable, honesto, hermoso y excelente".

\subsection{Pureza del cuerpo de Cristo por la materia de que fue formado}

El cuerpo de Cristo fue formado de "la misma pureza de la sangre santísima de la Virgen, criada y encerrada en sus limpias entrañas". La calidad misma de la sangre "fue la más apurada 171 y más limpia... y de más buenas cualidades de todas".

Fray Luis parte, además, de la influencia normal del alma en el cuerpo y aplica esta idea al influjo del alma purísima de la Virgen en la pureza del cuerpo de Cristo. El alma santísima de la Virgen, dice, "hacía santidad 172 en su sangre, y sus inclinaciones celestiales de ella; y los bienes del cielo sin cuento que en sí tenía, la espiritualizaban y santificaban en una cierta manera" 173.

Hace una reflexión místico-teológica sutilísima sobre la pureza de la sangre de la Virgen, cuando dice que "era la flor de la sangre..., y más adelgazada en pureza que, en género de sangre, después de la de su Hijo, jamás hubo en la tierra" 174 .

Para fray Luis, todas las purificaciones de la antigua Ley fueron encaminadas a purificar más y más la sangre de la Virgen, de la que nacería Cristo. Lo dice con palabras de belleza incomparable: "Todas las santificaciones y limpiezas de la Ley de Moisén..., los lavatorios, ayunos..., todo se ordenó para que, adelgazando y desnudando de sus afectos brutos la sangre y los cuerpos, y de unos en otros apurándose siempre más ${ }^{175}$, como en el arte de destilar

170. En la descripción que hace aquí sobre la estructura y composición de los diversos cuerpos, Fray Luis mezcla los aspectos fisiológico y psicológico y moral, ateniéndose, lógicamente, a los conocimientos que había en su tiempo.

171. "apurada" = purificada, delgada, sutil.

172. "hacía santidad" = santificaba, purificaba.

173. "La espiritualizaban y santificaban": Es indudable el influjo del cuerpo en el alma y, sobre todo, del alma en el cuerpo. Fray Luis alude aqui a la pureza de la sangre de Cristo por el influjo del alma purísima de la Virgen, en su mismo cuerpo y por tanto en la pureza del cuerpo de Cristo, formado en el seno de María.

174. Fray Luis se muestra con frecuencia ferviente defensor de la pureza de la Virgen María. Respecto a esto v. S. GoNZALEZ, "Títulos Cristológicos: "Pimpollo... En el c. 5: "Hijo de Dios" Segundo nacimiento: "Cristo nació de la Virgen María en cuanto hombre", "Estudio Agustiniano". Zamora, 1995 pp. 268 y nota 4; 270 y nota $13 ; 271$ y nota 19.

175. "apurándose siempre más" = purificándose más y más. 
acontece ${ }^{176}$, viniese últimamente una docella a hacer una sangre virginal por todo extremo limpísima, que fuese materia del cuerpo, purísimo sobre todo extremo, de Cristo".

Las ceremonias de purificaciones en la antigua Ley, que a nosotros nos parecen a veces extrañas y caprichosas, tuvieron un simbolismo profundo: el de que, por filtraciones y limpiezas sucesivas, se llegara a la pura y aromada flor de la virginidad de María. Fueron, dice fray Luis, "como un destilatorio, que de un licor puro sacando otro más puro, por medio de fuego y vasos diferentes, llegue a la sutileza y pureza postrera".

La sangre de la Virgen fue, pues, "la flor de la sangre ${ }^{177}$, de que se compuso todo el cuerpo de Cristo".

\subsection{Pureza del de Cristo por la leche purísima de que se nutrió}

La argumentación originalísima de fray Luis, de belleza incomparable, sobre la pureza de la sangre de María de que es formado el cuerpo, continuó después, en el primer tiempo de la vida de Jesús, cuando la Virgen alimentaba al Niño.

"Y no solo (dice) aquesta sangre virginal le compuso mientras estuvo en el vientre sagrado, mas, después que salió de él, le mantuvo, vuelta en leche ${ }^{178}$, en los pechos santísimos. De donde la divina Virgen, aplicando a ellos 179 a su Hijo de nuevo, y enclavando en Él los ojos y mirándole y siendo mirada de Él dulcemente..., abrasada en nuevo y castísimo amor, se la daba, si decir se puede, más santa y más pura... Se encontraban por los ojos las dos almas bellísimas, y se trocaban ${ }^{180}$ los espíritus, que hacen paso por ellos, con los del Hijo deificaba la Madre más, daba al Hijo más deificada la leche. Y como en la divinidad nace luz del Padre, que es Luz, así también, cuanto a lo que toca a su cuerpo, nace, de pureza, pureza" 181.

Los ojos de la Madre y del Hijo se encontraban y se intercambiaban los espíritus con inefable amor. La Madre era sublimada y deificada por el Hijo de manera semejante a como acontece entre el Hijo, Luz del Padre, que es Luz y fuente de toda Luz.

176. "como en el arte de destilar acontece" = e. d. empleando filtros cada vez más finos y sutiles.

177. "la flor de la sangre" = la sangre más pura y más acendrada, la quintaesencia misma de la sangre.

178. "vuelta en leche" = converida en leche la sangre.

179. "aplicando a ellos a su Hijo" = dando el pecho a su Hijo.

180. "se trastocaban" = se cambiaban.

181. Todo este pasaje, dice con acierto el P. Félix García, "es de una belleza extraordinaria, y explica, con una originalidad y hondura, el misterio de la pureza de María, que difícilmente han sido superadas": BAC 817. 


\subsection{Pureza de Cristo por el divino Artífice que formó su cuerpo}

Fray Luis termina y apura aún más finamente, con broche de oro, esta argumentación: "Y... ¿qué podremos decir por parte del divino Artífice que le compuso?... En este edificio del santísimo cuerpo de Cristo el Espíritu Santo... formó por su mano... y sin que interviniese otro ninguno, este cuerpo".

Concluye esta finísima argumentación con esta reflexión de carácter profundamente místico: "Si son perfectas todas las obras que Dios hace por sí 182, ésta que hizo para sí, ¿qué será?"

\section{Pureza del alma de Cristo}

Fray Luis avanza en su discurso. Cristo es purísimo en su alma. El razonamiento que emplea es de cuño típicamente aristotélico-escolástico.

\subsection{Respecto al alma, Cristo es purísimo}

Veamos el razonamiento: "Si hay respecto ${ }^{183}$... en las almas ${ }^{184}$, la de Cristo, fabricada por Dios para ser la del más perfecto cuerpo... que jamás se compuso, forzosamente diremos que..., de su naturaleza misma, está dotada sobre todas las otras, de maravillosa virtud y fuerza para toda santidad y grandeza". Y continúa más adelante: "Su alma, por la natural perfección y virtud que tenía, aspiró siempre a todo lo excelente y perfecto".

Al hablar del alma de Cristo, fray Luis parte del principio de que, dentro su naturaleza específica: sustancias espirituales, intrínsecamente independientes de la materia en su ser y en su obrar específico: espiritualidad, libertad, responsabilidad etc., las almas son distintas, más o menos perfectas, y proporcionadas siempre a la perfección de los cuerpos a que son destinadas. Ahora bien, el cuerpo de Cristo es el más perfecto formado por Dios. Su alma, por tanto, es la más perfecta y la más santa que Dios ha creado.

Por eso dice fray Luis: "Como la compostura del cuerpo era para mansedumbre dispuesta ${ }^{185}$, así el alma, de su vigor natural, era hábil para lo generoso y valiente. Y... como el cuerpo era hecho para instrumento de todo bien, así el alma tuvo natural habilidad para ser ejecutora de toda grandeza".

Fray Luis ha seguido aquí el mismo razonamiento del punto anterior: $\mathrm{Si}$ el cuerpo de Cristo 186 fue el más perfecto y el más inclinado al bien de cuan-

182. "por sî" = por su gloria, o, tal vez:"por la naturaleza misma de cada criatura (v. Gen c. 1).

183. "respecto" = proporción, relación.

184. "respecto... en las almas" = con los cuerpos a que son destinadas.

185. "para mansedumbre dispuesta" = para un cuerpo mansísimo: cf. Mt 11,29.

186. "si el cuerpo de Cristo" = supuesto o dado que el cuerpo de Cristo. 
tos han existido, su alma, creada para informar al cuerpo, fue la más santa y más digna de cuantas han existido. Es decir, tuvo la suma perfección posible, la suma santidad y pureza debidas a la naturaleza espiritual de las almas, y hubo siempre entre el alma y el cuerpo perfecta armonía para todo lo bueno y hermoso.

\subsection{Pureza de Cristo por la plenitud de gracia que recibe}

La gracia adornó el alma de Cristo con todas las virtudes. Fray Luis lo expresa con estas hermosas palabras:

No hay "virtud heroica, ni excelencia divina, ni belleza del cielo, ni dones y grandezas de espíritu, ni ornamento admirable y nunca visto, que no resida en su alma y no viva en ella sin medida ni tasa" 187 .

Apoya estas palabras en estos textos de la Escritura:

a) Evangelio de san Juan: "No le dio Dios con mano limitada su Espíritu" ${ }^{188}$. Cristo recibe el Espíritu sin medida.

b) Y en estas palabras del Apóstol: "En Cristo mora la plenitud de la divinidad" ${ }^{189}$. Habita "corporalmente". En Cristo se une el mundo divino entero, al que él pertenece, porque el mundo fue creado por él, y Cristo, que ahora ha sido glorificado, asumió directamente la humanidad e indirectamente todo el cosmos, creado para servicicio del hombre. En Cristo vive, pues, la plenitud del ser y de la perfección.

c) Y en Isaías 190: "Reposará sobre él el Espíritu del Señor”. El Espíritu profético será dado al Mesías ${ }^{191}$ y desplegará en él su exprexión definitiva ${ }^{192}$.

d) Y, finalmente, en el Salmo 44: "Por eso el Señor, tu Dios, te ungió con unción de alegría sobre todos tus compañeros" 193.

Fray Luis concluye de todos estos textos de la Escritura que la gracia y la virtud divina que el alma de Cristo atesora "era mayor en grandeza que las virtudes y gracias fundidas ${ }^{194}$, y hechas una de todos los que han sido justos".

Cristo es, pues, fuente inagotable de donde manan todas las gracias de las criaturas y excede a todas en virtud y justicia, como un abismo verdadero de todo bien.

187. BAC 820; AP 605-606.

188. Jn 3,34 .

189. Col 2,9.

190. Is 11,$2 ; 42,1 ; 62,1 \mathrm{~s} ; 63,10-13 ;$ Sal 51,$13 ; 56,1-5$.

191. J1 3, 1-2.

192. Cf. In 1,$33 ; 14,16 ;$ Hch 1,$8 ;$ Rom 5,5 .

193. Sal $44,8:$ "tus compañeros" = en el texto "tus particioneros".

194. "fundidas" = reunidas. 
Fray Luis concluye esta reflexión, a manera de una oración de gran belleza teológico-mística:

"Esta divina alma, para quien y cuyo servicio esta máquina universal fue criada ${ }^{195}$..., en sí abarca y contiene lo bueno todo ${ }^{196}$, lo admirable y lo divino".

Y ofrece la razón teológica de esta belleza, inspirada en el razonamiento de la unión personal con el Verbo, que va a emplear en el punto siguiente:

"Como ${ }^{197}$ el divino Verbo es una imagen del Padre, viva y expresa, que contiene en sí cuantas perfecciones Dios tiene, así 198 esta alma soberana... tan de cerca mira en $\mathrm{El}$ y se espeja ${ }^{199}$, y recibiendo en sí sus resplandores divinos, se fecunda y figura 200 y viste".

Es la misma imagen que ha empleado anteriormente, al hablar de la mirada de ternura y amor entre la Virgen y Jesús niño, para explicar la pureza del cuerpo de Cristo.

No hay imagen, añade, "como el alma de Cristo; y los mismos querubines más altos, son rasguños 201 imperfectos y sombras oscurísimas... en su comparación”.

\subsection{Pureza de Cristo por la unión personal con el Verbo}

Las dos naturalezas en Cristo están unidas en la única persona divina 202: en la segunda persona, la única persona encarnada de la Trinidad. Cristo, Dios y hombre, es realmente una sola persona ${ }^{203}$. Es, por tanto, Dios-hombre, hombre-Dios ${ }^{204}$. De la unicidad de persona en Cristo se sigue la predicación recíproca de propiedades y acciones 205 .

Fray Luis expresa esta doctrina con estas bellas y precisas palabras: “¿Qué diré... de... el lazo que con el Verbo divino tiene, y la personal unión, que ella sola... es justicia y riqueza inmensa? Porque ayuntándose el Verbo con aquella dichosa ánima, y por ella también con su cuerpo, así la penetra toda... que... no sólo mora Dios en Él, mas es Dios aquel hombre y tiene aquella alma en sí todo cuanto Dios es: su ser, su saber, su bondad, su poder. Y no... puede desprenderse de él o desenlazarse, ni es posible... que no viva y se conserve en suma perfección de justicia".

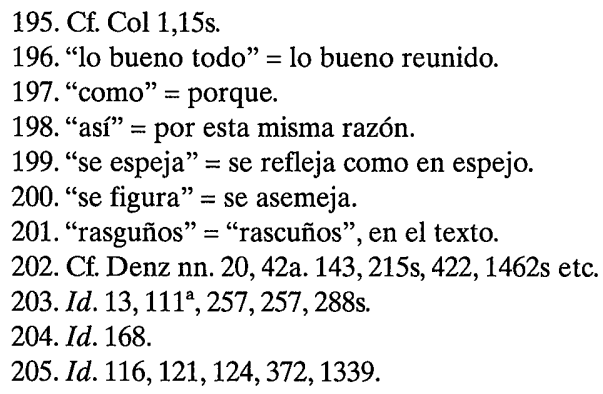


Para explicar esta doctrina, fray Luis recuerda el ejemplo del fuego aplicado al madero y al hierro, que se transforman en fuego, empleado en varios lugares de los Nombres 206: "Como el hierro que la fragua enciende, penetrado y poseído del fuego, y que parece otro fuego, siempre que está en la hornaza es y parece otro fuego..., así lanzada toda aquella feliz humanidad, y sumida por todos sus poros de aquel fuego divino..., es un hombre que es Dios..., y cuanto está lejos del no lo ser, tanto está apartado de no tener en su alma toda inocencia y rectitud y justicia".

Consecuencias de la unión personal:

$\left.1^{a}\right)$ Cristo tuvo la visión beatífica desde su concepción 207.

$\left.2^{a}\right)$ Tuvo ciencia infinita, es decir, todas las cosas que Dios conoce por su ciencia de visión 208 .

$3^{a}$ ) Tuvo la plenitud de los dones del Espíritu Santo 209.

$\left.4^{a}\right)$ Cristo era infinitamente santo, con la santidad propia de Dios y absolutamente impecable, porque era personalmente el mismo Dios 210.

$\left.5^{a}\right)$ Fue perfectamente libre, incluso en su pasión y muerte 211.

$\left.6^{a}\right)$ La humanidad de Cristo debe ser adorada por estar unida a la divinidad 212 y no debe prescindirse de la humanidad de Cristo ni siquiera en los grados más altos de la contemplación mística 213.

Fray Luis explica esta doctrina con gran belleza literaria y precisión teológica: "Así 214 lanzada toda aquella feliz humanidad, $y$ sumida en el abismo de Dios, $y$ poseída enteramente $y^{215}$ penetrada por todos su poros de aquel fuego divino, y firmado 216 es un hombre que es Dios.... y cuanto está lejos de no lo ser, tanto está apartado de no tener en su alma toda inocencia y rectitud de justicia" 217.

206. Cf. S. GonZÁlez, "Títulos Cristológicos", pp. 155 ss., donde se estudian las diversas imágenes que emplea fray Luis para explicar la "unión transformante" del alma.

207. Denz 2289.

208. Id. 2184.

209. Id. 83.

210. Id. 224.

211. Id. 255.

212. Id. $120 ; 1561$.

213. Id. 478

214. "asî" = de esta manera, al modo que hace el "fuego" con el "hierro", imagen empleada un poco antes.

215. $y+y^{*} y=$ obsérvese la profusión de esta conjunción, polisíndeton, para expresar los infinitos bienes que tiene la humanidad de Cristo por razón de la "unión hipostática" o personal con el Verbo.

216. "firmado" = afirmado, asegurado.

217. BAC 821-822; AP 608. 


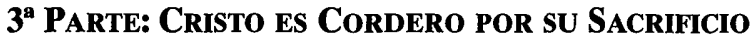

El comienzo de esta parte parece una obertura musical, llena, sin embargo, de realismo teológico-místico.

Para ser Cristo Cordero cabalmente y del todo, "se hizo nuestro único y perfecto sacrificio, aceptando y padeciendo, por darnos justicia y vida, muerte afrentosa en la cruz, en que ofrece a la lengua infinito" 218.

Fray Luis recuerda de nuevo el paso de san Juan, arriba estudiado: "He aquí el Cordero de Dios, que quita el pecado del mundo" 219 y lo interpreta con agudeza: Quita los pecados de nosotros, "los carga sobre sí mismo y los hace como suyos, para ser Él castigado por ellos, y que quedásemos libres". Esto, dice, expresa la fuerza misma de la palabra 220.

El título Cordero de Dios implica el significado escatológico decisivo de que se lleva el pecado y se presenta como el portador de la salvación. Jesús es, en efecto, el que da la salvación, porque quita el pecado del mundo.

\section{Cristo cargó a nosotros y a nuestros pecados}

La interpretación que hace fray Luis es precisa: Jesús nos toma primero a nosotros y a nuestros pecados en sí, los junta consigo y carga con ellos, "para que, padeciendo Él, padeciesen los que con Él estaban juntos y fuesen allí castigados".

Y aclara su pensamiento: "Como acaece a los árboles que son sin fruto en el suelo do nacen, y transplantados de él fructifican, así nosotros, traspasados en Cristo 221 , morimos sin pena y fuenos fructuosa la muerte".

La precisión teológica es sorprendente. Por una parte, "nos convenía morir ${ }^{222}$, y por otra, siendo nuestra, era inútil la muerte, y así 223 fue necesario... que miriésemos nosotros en otro que fuese tal y tan justo, que por ser en Él tuviese tanto valor nuestra muerte, que nos acarrease la vida" 224.

Cita la actitud israelita en el gran día de la expiación, que incorporó el jahvismo, exorcizando la vieja costumbre popular, cuando el sacerdote ponía

218. "a la lengua infinito" = no explicable con palabras.

219. Jn 1,19.

220. "quita": "tolle", en latín = aniquila, lleva consigo; "aírw" y airéw", en griego = llevar, apartar, abolir.

221. "traspasados en Cristo". Respecto a esto, ver J. L. Hervas, "Entrañados en Cristo. La Místicca Teológica de fray Luis de León”. Ed. Eunate, Pamplona 1996. El autor utiliza sobre todo "De los nombres de Cristo" y el "Comentario a los Gálatas", donde fray Luis aborda la doctrina paulina sobre nuestra vida en Cristo.

222. "nos convenía morir" = debíamos morir.

223. "y así" = y por este motivo.

224. BAC 823; AP 610. 
las manos sobre el macho cabrío 225 que cargaba en ella todo lo que la gente pecaba, así él, porque era también sacerdote ${ }^{226}$, puso sobre sí mismo las culpas y las personas y las juntó con su alma, como en el pasado se dijo 227.

Fray Luis hace ver cómo Dios unió en la humanidad de su Hijo a los hombres que estaban fuera de ella y los hizo tan unos con Él, "que se comunicaron entre sí y a veces 228 sus males y sus bienes y sus condiciones, y, muriendo Él, morimos de fuerza 229 nosotros, y, padeciendo el Cordero, padecimos en Él y pagamos la pena qu debíamos por nuestros pecados".

Cristo hizo suyos los pecados de los hombres "y tan allegados a sí mismo y tan juntos, que se le pegaron las culpas de ellos".

Cita, al efecto, estas palabras del salmo ventiuno, que pone san Mateo en boca de Jesús crucificado: ;Cuán lejos de mi salud las voces de mis delitos! 230. El mismo grito inicial: ¡Dios mío, Dios mío! ¿Por qué me has abandonado? 231, expresa la tragedia interior de Jesús, despreciado por los suyos, sometido al sufrimiento y abandonado por Dios.

En boca de Jesús crucificado 232 y citado por los relatos evangélicos de la pasión ${ }^{233}$, el salmo obtiene un nuevo sentido. Jesús "fue sometido al sufrimiento y a la prueba, y por eso puede ayudar ahora a los que están bajo la prueba" 234 .

Fray Luis lo expresa de esta manera: "Pudo tener en Él asiento lo que no podía ser hecho, ni obrado por Él. En que se consideran dos cosas: la fuerza del amor, y la grandeza de la pena y el dolor".

\section{Grandeza de su amor y dolor}

Fray Luis anota con agudeza por qué ésta es "una de las mayores penas de Cristo", y que ésta fue una de las causas de que le pusieron en agonía y sudor de sangre en el huerto 235 .

La escena del huerto es la más dramática, tal vez, de todo el nuevo testamento, el punto culminante de la pasión de Jesús y el más desconcertante para la razón humana. Jesús sufre en su pasión los tormentos que le infligen los

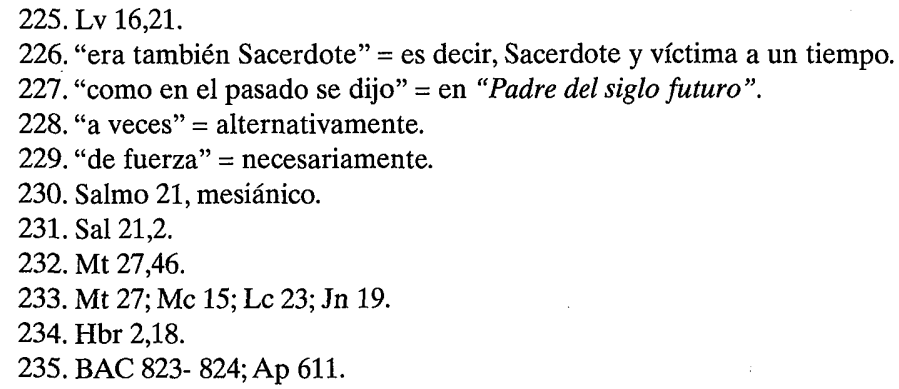


hombres, pero en su agonía los que Él mismo se aplica. Es la lucha entre el amor y la pena interior.

Jesús en el huerto aparece hundido hasta tal punto en la miseria humana, que parece sumirse en la misma miseria, vuelto Él mismo miseria. Fray Luis lo expresa con precisión teológica: "Dejando aparte el ejército de dolores... de que dijimos arriba ${ }^{236}$, ¿qué sentimiento sería..., qué congoja, qué ansia... cuando Él..., vio que tanta muchedumbre de culpas, cuantas son las que desde el principio hasta el fin cometen los hombres..., se le avecinaban al alma, y cercaban y rodeaban, y cargaban sobre ella, y verdaderamente se le apegaban y hacían como suyas sin serlo ni haberlo podido ser".

La serenidad y transparencia de Jesús, el poder realizar cuanto quiere, hablando y actuando siempre con majestad, seguro siempre de sí mismo, se quiebra en el huerto y se cambia ahora en vacilación y tristeza. Lo vemos ahora angustiado, repitiendo una y otra vez la misma oración, como temiendo no ser oído por su Padre, mendigando el consuelo y la compañía de los suyos.

Los cuatro evangelistas, especialmente san Lucas, narran esta actitud de Jesús. Y, ciertamente, sin esto no habríamos entendido hasta qué profundidad asumió Jesús nuestra humanidad, y no hubiéramos conocido la verdadera realidad de Cristo. Ninguna página del Evangelio nos explica con tanta claridad el misterio de las dos naturalezas de Cristo, la humana y la divina, con sus especificaciones distintas.

Jesús vio entonces la mediocridad de los elegidos, las traiciones a su Evangelio, las cobardías de los cristianos. Y esto nos hace comprender un poco el sudor de sangre.

Fray Luis presenta este momento histórico como una lucha entre aspectos diametralmente opuestos, que irrumpieron sobre el alma de Jesús: ¿Qué agonía dice, y "qué tormento tan grande, y quien aborreció tanto este mal 237, y quien veía a los ojos, cuánto de Dios aborrecido era y huído, verse de él tan cargado?".

Y especifica luego algunos contrastes más dolorosos:

a) Se veía leproso, $b$ ) el que era la salud de la lepra;

a) vestido de injusticia y maldad, b) el que era la misma justicia;

a) herido y azotado y como desecho de Dios, $b$ ) el que sanaba las heridas nuestras y era el descanso del Padre?

Y termina con esta reflexión místico-contemplativa:

236. "Rey de Dios" = BAC 580ss; AP 259ss.

237. "aborreció tanto este mal" = el pecado. 
Fue "terrible congoja el unir consigo Cristo purísimo, inocentísimo y justísimo tantos pecadores y culpas, y el vestirse tal Rey de tanta dignidad, de nuestra vejez y vileza".

\section{EI sacrificio de su corazón}

Para fray Luis, el mismo hecho de "hacerse Cordero de sacrificio, y poner en sí las condicciones y cualidades al Cordero, que, sacrificado, limpiaba, fue en cierta manera un gran sacrificio".

Esto explica que, antes de subir a la cruz, "le era cruz esa misma carga, que para subir a ella sobre sus hombros ponía".

Para fray Luis era menos tormento para Jesús el desatarse ${ }^{238}$ su cuerpo que el unirse en el mismo templo de la santidad 239 tan gran torpeza.

Y especifica algunos contrastes, contraponiéndolos, a la torpeza de la maldad de los hombres:

a) "Por una parte, su santa ánima la abrazaba y recogía en sí, para deshacerla, por el infinito amor que nos tiene;

b) "y por otra, esquivaba y huía su vecindad y su vista, movido de su infinita limpieza.

c) "Y así peleaba y agonizaba y ardía como sacrificio aceptísimo".

Y termina con estas palabras de hondo significado místico. De suerte que:

a) "Ardiendo Él, b) ardieron en Él nuestas culpas;"

a) "y bañándose su cuerpo de sangre, $b$ ) se bañaron en sangre los pecadores;

a) "y muriendo el Cordero, b) todos los que estaban en Él... pagaron lo que el rigor de la ley requería".

La obertura inicial de ese nombre se cierra con estas palabras de musicalidad mística inigualable:

"Así fue justísimo que ardiendo en el ara de la cruz y sacrificándose este dulce Cordero, en quien estaban encerrados y como hechos uno todos los suyos, cuanto es de su parte 240 , quedasen abrasados todos y limpios".

$Y$ Marcelo concluye: "De lo cual, Juliano, veréis con cuánta razón se llama Cristo Cordero".

SERGIO GonZÁlEZ

Estudio Teológico Agustiniano

VALLADOLID

238. "desatarse" $=$ deshacerse.

239. "en el mismo templo" = el alma de Jesús.

240. "cuanto es de su parte" = obsérvese la precisión teológica: porque falta, lógicamene, la colaboracíon indispensable y libre del hombre. 